\title{
Pengembangan Model Pembelajaran Passing Atas Bola Voli Berbasis Permainan
}

\section{Development of Passing Learning Model to Based Games Volley Ball}

\author{
Aep Rohendi \\ STKIP Pasundan, Cimahi, Jawa Barat, Indonesia \\ aeprohendi22@gmail.com
}

\begin{abstract}
Abstrak
Penelitian ini bertujuan untuk meningkatkan pembelajaran Passing atas di STKIP Pasundan Cimahi. Metode yang digunakan untuk mengungkap permasalahan ini adalah metode model pengembangan Research \& develoment $(R \& D)$ dari Borg dan Gall. Sampel penelitian ini berjumlah 80 orang siswa, 40 orang sebagai kelompok control dan 40 orang sebagai kelompok eksperimen. Hasil penelitian ini telah menjawab tentang efektifitas dari penghitungan diperoleh nilai F-hitung untuk kelas kontrol adalah 1,541 dan F-tabel $=4.091$. F-hitung untuk kelas eksperimen adalah 1,017 dan F-tabel = 4,091 sehingga dapat dinyatakan bahwa data tes awal dan tes akhir kelas eksperimen itu homogen. Berdasarkan perhitungan indeks gain, didapatkan bahwa gain untuk kelas eksperimen adalah sebesar 0,705. Nilai ini diinterpretasikan termasuk kategori tinggi. Dengan kata lain kemampuan siswa pada dapat meningkat setelah diberikan pembelajaran Passing atas bola voli berbasis permainan.
\end{abstract}

Kata Kunci: Pembelajaran Passing Atas Bola Voli, Pengembangan Model.

\begin{abstract}
This study aims to improve Passing learning in STKIP Pasundan Cimahi. The method used to uncover this problem is the research \& development $(R \& D)$ development model of Borg and Gall. The sample of this study was 80 people, 40 people as control group and 40 people as experimental group. The results of this study have answered about the effectiveness of counting values for the class is 1.541 and F-table $=4.091 . F$-count for the experimental class is 1.017 and F-table $=4.091$ which can be expressed as preliminary test data and the experimental class final test is homogeneous. Based on the index gain, the gain for the experimental class is 0.705. This value is interpreted to be in the high category. In other words, the student's ability to increase after a given Passing learning on game-based bola voli.
\end{abstract}

Keywords: Passing Learning on Volleyball, Model Development. 


\section{PENDAHULUAN}

Bermain dan permainan merupakan dua kata istilah yang sering dipakai secara bergantian. Bermain adalah kata kerja dan permainan adalah kata benda. Anak bermain berarti anak melakukan suatu permainan. Permainan dibagi menjadi empat katagori utama (1) agon permainan yang bersifat pertandingan, perlawanan kedua pihak. (2) alea permainan yang mengandalkan hasil secara untunguntungan. (3) mimikri permainan fantasi. (4) illinx permainan yang termasuk ke dalam olahraga. (Husdarta, 2010).

Bola voli adalah suatu olahraga beregu yang dimainkan oleh dua regu yang masing-masing terdiri dari enam orang tiap regunya yang dipisahkan oleh net (Cimenli, Ozkan, et al, 2016). Permainan bola voli merupakan olahraga populer yang memiliki ribuan pendukung dan praktisi di dunia Internasional juga bola voli merupakan olahraga kompetitif yang dimainkan di berbagai permukaan seperti di dalam ruangan atau di luar ruangan dan bola voli merupakan permainan yang intermiten yang diselangi dengan tempo cepat dan kadang-kadang tempo yang rendah serta dimainkan pada permukaan datar dan keras yang terbuat dari kayu atau bahan sintetis (Cimenli., Ozkan, et al, 2016). Dari sudut pandang lain, bola voli merupakan olahraga yang unik karena olahraga ini merupakan permainan kesalahan yang memiliki tujuan mendapatkan bola untuk dipukulkan ke daerah lapangan lawan atau memaksa lawan membuat kesalahan dalam menangani bola (American Sport Education Program, 2008). Bola voli modern memiliki harapan tinggi untuk manifestasi aktivitas gerak di mana pemain dengan motorik tingkat tinggi dan kemampuan fungsional dapat mengekspresikan karakteristik teknis dan taktis yang tepat selama pertandingan (Bojanic, et al, 2016). Dalam era modern Permainan bola voli modern membutuhkan semua pemain untuk memiliki keterampilan motorik umum dan khusus tingkat tinggi (Bojanic, et al, 2016).

Penelitian dan pengembangan atau dalam bahasa inggrisnya research and development merupakan penelitian yang digunakan untuk meneliti sehingga menghasilkan produk baru, dan menguji keefektifan produk tersebut (Sugiono, 2011). Penelitian pengembangan sendiri bukan untuk merumuskan atau menguji teori, tetapi untuk mengembangkan produk-produk yang efektif untuk digunakan di sekolah-sekolah dan mengemukakan kembali produk-produk yang dihasilkan oleh penelitian dan pengembangan mencakup: materi pelatihan guru, materi ajar, seperangkat tujuan perilaku, materi media, dan sistem-sistem manajemen (Emzir, 2012). Dalam pengembangan lainnya perkembangan teknologi untuk melacak objek bergerak seperti bola, telah menggunakan melalui dukungan fotogrametri 2D, serta dengan 3D fotogrametri (Jlassi, et al, 2012).

Setiap model pembelajaran dirancang untuk mempromosikan jenis hasil belajar tertentu bagi siswa dan untuk mengatasi berbagai kombinasi standar nasional, oleh itu karena setiap model yang dapat digunakan dalam pendidikan jasmani (Gurvitch \& Metzler, 2013) Model pembelajaran adalah pembangkitan respon dengan stimulus yang pada mulanya bersipat netral (Hamalik, 2012). Model 
bukanlah realitis, akan tetapi merupakan resprentative realitas yang dikembangkan dari keadaan. Model sendiri merupakan pengkonkritan suatu teori atau gambaran proses dan variabel yang tercakup dalam teori serta model dikatakan memadai apabila memiliki kesanggupan menghasilkan data yang sama seperti objek yang sesungguhnya juga menyerupai objek sebagaimana nyatanya (Sudjana, 2011). Lebih lanjut, model pembelajaran juga suatu perencanaan atau suatu pola yang digunakan sebagai pedoman dalam merencanakan pembelajaran di kelas atau pembelajaran dalam tutorial (Trianto, 2012). Pembelajaran langsung adalah pembelajaran model yang dirancang untuk mengajarkan pengatahuan deklaratif dan pengatahuan prosedural yang diajarkan setahap demi setahap dan Bandura menguraikan kembali belajar melalui observasi jauh lebih efisien dibanding belajar melalui pengalaman langsung (Rahyudi, 2012).

Passing atas adalah pukulan yang dilakukan pemain dengan menyentuh bola dengan kedua tangan di atas kepala pemain yang melakukan pemain kontak kedua dan mengarahkan bola kepada penyerang (Rohendi \& Suwandar, 2017). Passing atas adalah cara memainkan bolapertama setelah bola berada dalam permainan akibat dari serangan lawan, servis lawan atau permainan net (Subroto \& Yudiana, 2010). Persiapan bergerak ke arah bola, siapkan posisi, bahu sejajar sasaran, kaki merenggang santai, bengkokkan sedikit lengan, kaki dan pinggul, tahan tangan 6 atau 8 inci di atas pelipis, tahan tangan di depan pelipis, melihat melalui "jendela" yang dibentuk tangan, ikuti bola ke sasaran. pelaksamaan terima bola pada bagian belakang bawah, terima dengan 2 persendian teratas dari jari dan ibu jari, luruskan tangan dan kaki ke arah sasaran, pindahkan berat badan ke arah sasaran, arahkan bola sesuai keting-gian yang diinginkan, arahkan bola ke garis pinggir atau ke tangan penyerang. gerak lanjutan luruskan tangan sepenuh-nya, arahkan bola ke sasaran, pinggul bergerak maju ke arah sasaran, pindahkan berat badan ke arah sasaran, bergerak ke arah umpan. (Kleinmann, 2012)

Berdasarkan latar belakang tersebut penulis tertarik untuk mengembangkan tentang "Pengembangan model pembelajaran pasing atas berbasis permainan". Yang akan merujuk ke teori Brog and Gall (1989) yang bertujuan untuk meningkatkan kualitas pendidikan. Produk yang dimaksud meliputi tiga pokok, yakni (1) produk tersebut meliputi baik perangkat keras maupun perangkat lunak, (2) produk merupakan produk baru atau bahkan modifikasi dari produk yang sudah ada, (3) produk benar-benar bermanfaat bagi pengembangan pendidikan. Proses pengembangan produk dalam praktiknya terdiri atas: analisis kebutuhan, pengembangan produk dan uji produk. Urutan-urutan itu mengindikasikan bahwa produk yang dikembangkan merupakan produk terencana dan teruji secara layak. Dengan demikian, penelitian pengembangan merupakan suatu penelitian yang mendasarkan pada pembuatan suatu produk yang efektif. 


\section{METODE PENELITIAN}

Dalam penelitian pengembangan model pembelajaran Passing atas bola voli berbasis bermain ini menggunakan model pengembangan Research \& develoment $(R \& D)$ yang merupakan suatu proses untuk mengembangkan dan memvalidasi produk pembelajaran (Borg \& Gall, 1989).

Tabel 1. Tahapan dan Langkah Penelitian Pengembangan

\begin{tabular}{|c|c|c|}
\hline Tahap & Langkah & Aktivitas \\
\hline \multirow[t]{2}{*}{ Pra Pengembangan } & 1 & $\begin{array}{l}\text { a. Pengumpulan data awal } \\
\text { b. Penyusunan Proposal penelitian } \\
\text { c. Analisis kebutuhan }\end{array}$ \\
\hline & 2 & Perencanaan produk \\
\hline \multirow[t]{3}{*}{ Pengembangan } & 3 & Perencanaan model latihan dan Video \\
\hline & 4 & $\begin{array}{l}\text { Evaluasi formatif: } \\
\text { Uji coba tahap (1) } \\
\text { Evaluasi ini dilakukan dengan rekan sejawat yang } \\
\text { memiliki kompetensi yang memadai dalam kontek: } \\
\text { materi, media teknologi dan desain pembelajaran. } \\
\text { Perbaikan awal. }\end{array}$ \\
\hline & 5 & $\begin{array}{l}\text { Evaluasi pakar (Expert juggment) dengan pakar penjas } \\
\text { dan pakar bola voli. } \\
\text { Perbaikan tahap (2) }\end{array}$ \\
\hline \multirow[t]{5}{*}{ Penerapan } & 6 & $\begin{array}{l}\text { Uji coba lapangan (2) } \\
\text { Evaluasi dengan skala terbatas } 40 \text { responden Perbaikan } \\
\text { operasional (1) }\end{array}$ \\
\hline & 7 & Uji coba efektivitas model \\
\hline & 8 & Evaluasi dengan skala terbatas 40 responden \\
\hline & 9 & Perbaikan operasional (2) \\
\hline & 10 & Produksi dan Penerapan Buku Panduan \\
\hline
\end{tabular}

\section{HASIL DAN PEMBAHASAN}

\section{Hasil}

Efektivitas pengembangan model pembelajaran Passing atas bola voli berbasis permainan ini didapatkan dari hasil uji coba pada kelompok kontrol dan kelompok eksperimen. Secara keseluruhan, deskripsi kelas kontrol dan kelas eksperimen pada tahap tes awal (pretest) dan tes akhir (posttest) dapat disajikan pada tabel sebagai berikut.

Tabel 2

\section{Deskripsi Kelas Kontrol dan Eksperimen}

\begin{tabular}{|c|l|r|r|r|}
\hline \multicolumn{1}{|c|}{ Tes } & \multicolumn{1}{|c|}{ Kelas } & \multicolumn{1}{c|}{ N } & \multicolumn{1}{c|}{$\begin{array}{c}\text { Rata- } \\
\text { Rata }\end{array}$} & \multicolumn{1}{c|}{$\begin{array}{c}\text { Standar } \\
\text { Deviasi }\end{array}$} \\
\hline \multirow{2}{*}{ Tes Awal } & Kontrol & 40 & 6,025 & 1,097 \\
\cline { 2 - 5 } & Eksperimen & 40 & 5,900 & 0,955 \\
\hline \multirow{2}{*}{ Tes Akhir } & Kontrol & 40 & 6,825 & 0,712 \\
\cline { 2 - 5 } & Eksperimen & 40 & 10,200 & 0,939 \\
\hline
\end{tabular}


Tabel di atas menunjukkan bahwa pada tes awal, rata-rata kelas kontrol $(6,025)$ berada di atas rata-rata kelas eksperimen (5,900). Adapun pada tes akhir, rata-rata kelas kontrol $(6,825)$ berada jauh di bawah kelas eksperimen $(10,200)$. Berikut disajikan ilustrasi mengenai deskripsi kelas kontrol dan eksperimen untuk tes awal dan tes akhir.

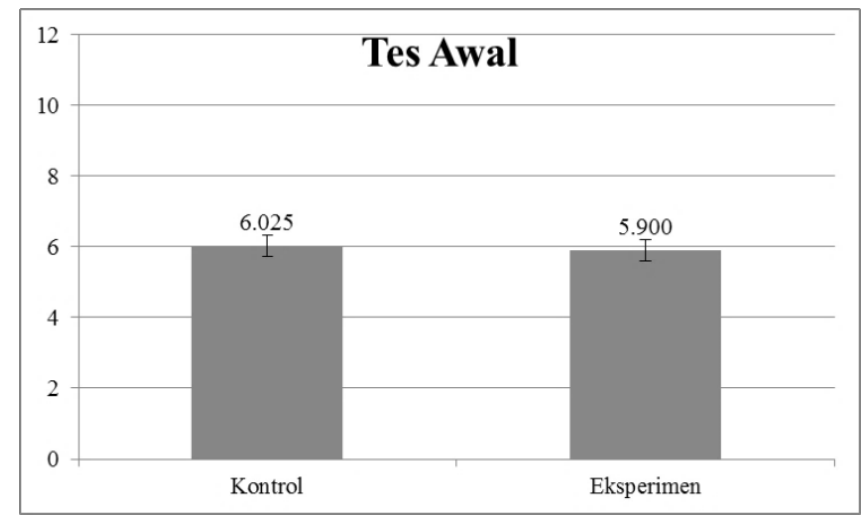

Gambar 1

Tes Awal Kelas Kontrol dan Eksperimen

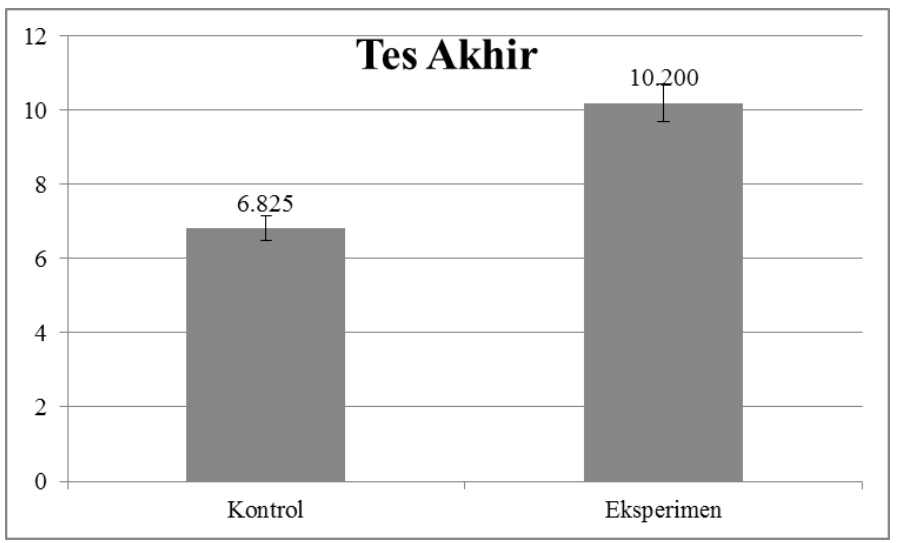

Gambar 2

Tes Akhir Kelas Kontrol dan Eksperimen

Mengacu pada hasil deskripsi sebelumnya, deskripsi kelas kontrol pada tahap tes awal (pretest) dan tes akhir (posttest) dapat disajikan pada tabel sebagai berikut.

Tabel 3

Deskripsi Kelas Kontrol

\begin{tabular}{|c|c|r|r|r|}
\hline Kelas & Kelas & N & \multicolumn{1}{c|}{$\begin{array}{c}\text { Rata- } \\
\text { Rata }\end{array}$} & \multicolumn{1}{c|}{$\begin{array}{c}\text { Standar } \\
\text { Deviasi }\end{array}$} \\
\hline \multirow{2}{*}{ Kontrol } & Tes Awal & 40 & 6,025 & 1,097 \\
\cline { 2 - 5 } & Tes Akhir & 40 & 6,825 & 0,712 \\
\hline
\end{tabular}

Rata-rata peningkatan (atau penurunan) dari tes awal ke tes akhir untuk kelas kontrol ini adalah sebesar 0,8, seperti yang tampak pada gambar sebagai berikut. 


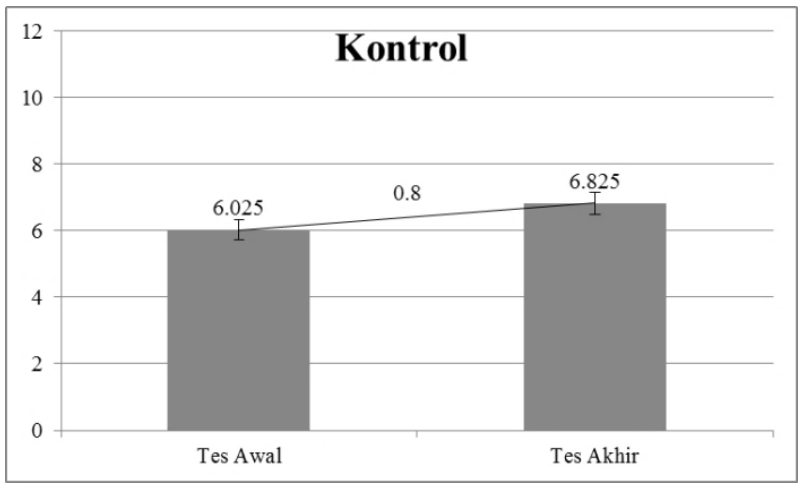

Gambar 3

Deskripsi Kelas Kontrol

Mengacu pada hasil deskripsi sebelumnya, deskripsi kelas eksperimen pada tahap tes awal (pretest) dan tes akhir (posttest) dapat disajikan pada tabel sebagai berikut.

Tabel 4

Deskripsi Kelas Eksperimen

\begin{tabular}{|c|c|r|r|r|}
\hline Kelas & Kelas & \multicolumn{1}{c|}{ N } & \multicolumn{1}{c|}{$\begin{array}{c}\text { Rata- } \\
\text { Rata }\end{array}$} & \multicolumn{1}{c|}{$\begin{array}{c}\text { Standar } \\
\text { Deviasi }\end{array}$} \\
\hline \multirow{2}{*}{ Eksperimen } & Tes Awal & 40 & 5,900 & 0,955 \\
\cline { 2 - 5 } & Tes Akhir & 40 & 10,200 & 0,939 \\
\hline
\end{tabular}

Rata-rata peningkatan (atau penurunan) dari tes awal ke tes akhir untuk kelas eksperimen ini adalah sebesar 4,3 seperti yang tampak pada gambar sebagai berikut.

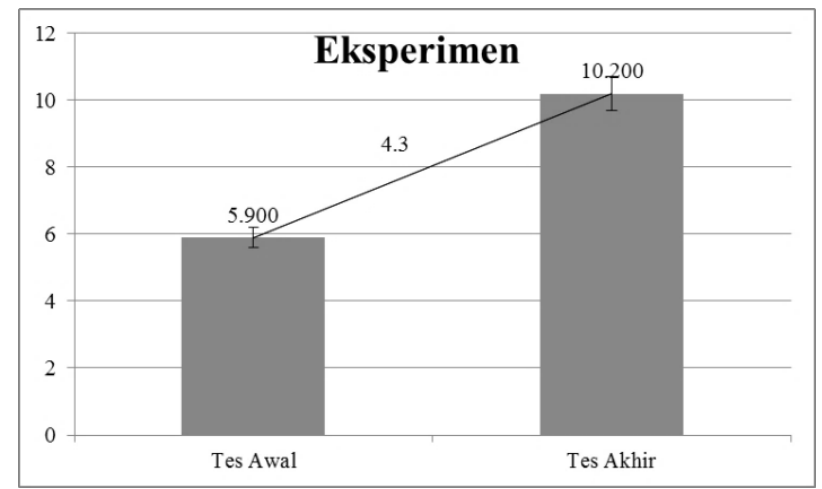

Gambar 4

Deskripsi Kelas Eksperimen

Sebelum dilakukan pengujian hipotesis uji beda dua rata-rata, terlebih dahulu dilakukan uji persyaratan data. Dalam hal ini, beberapa asumsi statistik perlu dipenuhi, yaitu normalitas dan homogenitas. Berikut ini disajikan masing-masing perhitungan asumsi statistiknya.

Uji normalitas dalam hal ini dihitung menggunakan uji Kolmogorov-Smirnov. Hasil perhitungan normalitas data untuk setiap kelas dan tes disajikan sebagai berikut. 
Tabel 5

Uji Normalitas

\begin{tabular}{|l|l|r|r|r|r|}
\hline \multicolumn{2}{|c|}{} & PRE_KON & PRE_EKS & POS_KON & POS_EKS \\
\hline $\mathrm{N}$ & Mean & 40 & 40 & 40 & 40 \\
\cline { 2 - 7 } Normal Parameters & Std. Deviation & 6.025 & 5.900 & 6.825 & 10.200 \\
\hline \multirow{4}{*}{ Most Extreme Differences } & Absolute & 1.097 & 0.955 & 0.712 & 0.939 \\
\cline { 2 - 7 } & Positive & 0.184 & 0.208 & 0.247 & 0.228 \\
\cline { 2 - 7 } & Negative & -0.166 & -0.192 & -0.247 & -0.228 \\
\hline Kolmogorov-Smirnov Z & & 1.164 & 1.318 & 1.563 & 1.441 \\
\hline Asymp. Sig. (2-tailed) & & 0.133 & 0.062 & 0.126 & 0.131 \\
\hline Nilai kritis & & 0.050 & 0.050 & 0.050 & 0.050 \\
\hline Keputusan & & Normal & Normal & Normal & Normal \\
\hline
\end{tabular}

Nilai signifikansi untuk setiap kelas dan tes lebih besar dari pada 0,05. Dengan demikian dapat disimpulkan bahwa semua kelas dan tes berdistribusi normal.

Pengujian homogenitas adalah pengujian mengenai sama tidaknya variansi-variansi dua buah distribusi atau lebih. Uji homogenitas di sini menggunakan Uji Homogenitas Variansi. Uji homogenitas dilakukan untuk mengetahui apakah data dalam dua sampel itu bersifat homogen atau tidak.

Uji homogenitas ini adalah membandingkan variansi atau standar deviasi untuk setiap data berpasangan. Berikut disajikan hasil uji homogenitas untuk setiap kelas.

\section{Tabel 6}

Uji Homogenitas

\begin{tabular}{|l|l|r|r|r|l|}
\hline Kelas & Tes & $\begin{array}{l}\text { Standar } \\
\text { Deviasi }\end{array}$ & F-hitung & F-tabel & Keputusan \\
\hline Kontrol & Tes Awal & 1,097 & 1,541 & 4,091 & Homogen \\
\hline & Tes Akhir & 0,712 & & & \\
\hline Eksperimen & Tes Awal & 0,955 & 1,017 & 4,091 & Homogen \\
\hline & Tes Akhir & 0,939 & & & \\
\hline
\end{tabular}

Dari penghitungan tersebut diperoleh nilai F-hitung untuk kelas kontrol adalah 1,541 dan Ftabel $=4.091$. Tampak bahwa $\mathrm{F}$ hitung $<\mathrm{F}$ tabel. Hal ini berarti data tes awal dan tes akhir untuk kelas kontrol itu homogen. Perhitungan ini juga berlaku untuk kelas eksperimen di mana F-hitung untuk kelas eksperimen adalah 1,017 dan F-tabel = 4,091 sehingga dapat dinyatakan bahwa data tes awal dan tes akhir kelas eksperimen itu homogen.

Secara keseluruhan, pengujian persyaratan hipotesis menunjukkan bahwa semua kelas dan tes berdistribusi normal. Selain itu, hasil perhitungan menunjukkan bahwa kelas dan tes itu homogen. Dengan demikian pengujian uji dua rata-rata menggunakan uji-t (parametrik) dapat digunakan. 
Pengujian hipotesis ini menggunakan uji-t dua rata-rata. Hipotesis statistiknya adalah:

$\mathrm{H}_{0}: \square \mathrm{k}-\square \mathrm{e}=0$; tidak terdapat perbedaan rata-rata antara kelas kontrol dan kelas eksperimen setelah pelaksanaan model pembelajaran keterampilan gerak Passing atas bola voli. $\mathrm{H}_{1}: \square \mathrm{k}-\square \mathrm{e} \neq 0$; tidak terdapat perbedaan rata-rata antara kelas kontrol dan kelas eksperimen setelah pelaksanaan model pembelajaran keterampilan gerak Passing atas bola voli.

Hasil perhitungan uji beda dua rata-rata menggunakan uji-t dihasilkan perhitungan sebagai berikut.

Tabel 7

Uji Hipotesis

\begin{tabular}{|c|l|l|l|l|l|c|c|c|}
\hline & N & $\begin{array}{l}\text { Levene's Test } \\
\text { for Equality of } \\
\text { Variances }\end{array}$ & \multicolumn{5}{|c|}{ t-test for Equality of Means } & \\
\cline { 2 - 8 } & & F & Sig. & T & Df & $\begin{array}{c}\text { Sig. (2- } \\
\text { tailed) }\end{array}$ & $\begin{array}{c}\text { Mean } \\
\text { Difference }\end{array}$ & Keterangan \\
\hline $\begin{array}{c}\text { Tes } \\
\text { Awal }\end{array}$ & 40 & 0,502 & 0,481 & 0,543 & 78 & 0,588 & 0,125 & $\begin{array}{c}\text { Tidak terdapat } \\
\text { perbedaan }\end{array}$ \\
\hline $\begin{array}{c}\text { Tes } \\
\text { Akhir }\end{array}$ & 40 & 3,877 & 0,052 & $-18,111$ & 78 & 0,000 & $-3,375$ & $\begin{array}{c}\text { Terdapat } \\
\text { perbedaan }\end{array}$ \\
\hline
\end{tabular}

Perhitungan tersebut menunjukkan bahwa pada tes awal tidak terdapat perbedaan rata-rata antara kelas kontrol dan kelas eksperimen. Dengan demikian disimpulkan bahwa pada awalnya, kemampuan siswa pada keterampilan gerak Passing atas bola voli pada kelas kontrol dan eksperimen itu tidak terdapat perbedaan. Dengan kata lain kemampuan kelas kontrol dan eksperimen pada awalnya sama.

Pada tes akhir ditemukan adanya perbedaan yang signifikan antara kelas kontrol dan kelas eksperimen. Hal ini dapat dilihat dari nilai t-hitung sebesar 18,111 yang lebih besar dari nilai ttabel, yaitu 2,022. Dengan kata lain, kemampuan kelas eksperimen yang mendapatkan pembelajaran Passing atas bola voli berbasis permainan berbeda secara signifikan dengan kemampuan kelas kontrol.

Untuk mengetahui peningkatan nilai pretes dan postes kelas eksperimen dan kelas kontrol, digunakan penghitungan indeks gain. Dalam penelitian ini, indeks gain digunakan apabila rata-rata nilai postes kelas eksperimen dan postes kelas kontrol berbeda. Rumus indeks gain (g) tersebut adalah sebagai berikut:

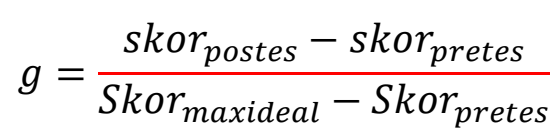


Tabel 8

Klasifikasi Interpretasi Nilai Gain Ternormalisasi

\begin{tabular}{|c|c|}
\hline Nilai Gain Ternormalisasi & Interpretasi \\
\hline $\mathrm{g}>0,70$ & Tinggi \\
\hline $0,30<\mathrm{g} \leq 0,70$ & Sedang \\
\hline $\mathrm{g} \leq 0,30$ & Rendah \\
\hline
\end{tabular}

Indeks gain untuk kelas eksperimen adalah:

$$
\begin{gathered}
g=\frac{10,2-5,9}{12-5,9} \\
g=0,705
\end{gathered}
$$

Berdasarkan perhitungan indeks gain di atas, didapatkan bahwa gain untuk kelas eksperimen adalah sebesar 0,705. Nilai ini diinterpretasikan termasuk kategori tinggi. Dengan kata lain kemampuan mahasiswa pada dapat meningkat setelah diberikan pembelajaran Passing atas bola voli berbasis permainan.

\section{Pembahasan}

Revisi Produk (Revisi Tahap 1)

Catatan ahli pembelajaran dan dosen PJKR sebagaimana dideskripsikan di bawah ini.

- Di dalam buku panduan diberi-kan keterangan mengenai porsi pembelajaran lebih banyak

- Memberikan kesempatan lebih banyak kepada siswa untuk mendapat kesempatan mencoba secara optimal

- Menyempurnakan gambar setiap gerakan menjadi lebih terang dengan upaya pewarnaan atau penebalan pada bagian-bagian tertentu

- Menyempurnakan media

- Menambah jumlah alat atau sarana pembelajaran Passing atas bola voli

- Memberikan game disertiap akhir pembelajaran

- Menyempurnakan pola pembelajaran Passing atas bola voli

- Menyempurnakan pola pembelajaran Passing atas bola voli dengan game yang sebenarnya.

Revisi Produk

- Di dalam buku panduan diberikan keterangan mengenai porsi pembelajaran lebih banyak.

- Memberikan kesempatan lebih banyak kepada mahasiswa untuk mendapat kesempatan mencoba secara optimal.

- Menyempurnakan gambar setiap gerakan menjadi lebih terang dengan upaya pewarnaan atau penebalan pada bagian-bagian tertentu. 
- Menyempurnakan media.

- Menambah jumlah alat atau sarana pembelajaran Passing atas bola voli.

- Memberikan game disertiap akhir pembelajaran.

- Menyempurnakan pola pembelajaran Passing atas bola voli.

- Menyempurnakan pola pembelajaran Passing atas bola voli dengan game yang sebenarnya.

\section{Revisi Tahap II}

Setelah melakukan revisi produk tahap 1, selanjutnya dilakukan uji coba kelompok kecil yang menghasilkan kesimpulan dan masukan guna direvisi pada perlakukan selanjutnya. Dari uji coba kelompok didapat catatan sebagai berikut.

- Pengulangan pembelajaran Passing atas bola voli secara individu maupun kelompok sebaiknya diperbanyak.

- Komposisi pembelajaran Passing atas bola voli sudah cukup baik, namun masih harus dikembangkan kemungkinan formasi lainnya.

- Dosen PJKR sebaiknya selalu memberikan motivasi pada setiap gerakan melalui ungkapan pujian atau koreksi langsung, atau juga dapat dilaksanakan saat evaluasi pasca pembelajaran pada setiap sesinya.

Adapun revisi yang dilakukan adalah :

- Memperbanyak jumlah porsi pengulangan latihan individu dan kelompok.

- Mengembangkan kemungkinan atau alternatif lainnya dari alternatif yang sudah ada.

- Poin-poin pemberian motivasi menjadi bagian khusus dalam penjelasan model pembelajaran Passing atas bola voli ini.

Sedangkan catatan lapangan yang berhasil diperoleh adalah :

- Saat melakukan pemanasan sebaiknya dilakukan dengan serius agar tidak terjadi cedera.

- Fun game atau pembelajaran berkelompok penting dilakukan untuk melihat seberapa banyak kemajuan yang dicapai setelah dilakukan pembelajaran Passing atas bola voli individu maupun kelompok.

- Pembelajaran Passing atas bola voli berbasis permainan dilakukan secara berulang-ulang akan menghasilkan otomatisasi pada setiap siswa.

\section{Revisi Tahap III}

Menurut para ahli dan berdasarkan jawaban angket pembelajaran Passing bawah bola voli dengan pendekatan bermain pada siswa sekolah sudah tidak memerlukan lagi revisi. Namun dari uji coba lapangan itu masih disertakan catatan lapangan. 
Catatan lapangan yang diperoleh dari uji coba lapangan adalah bahwa sistem pembelajaran sudah baik, tinggal mempertimbangkan durasi waktu pada setiap sesi pembelajaran Passing atas bola voli berbasis permainan, dengan ukuran harus sesuai dengan RPP.

\section{KESIMPULAN}

Berdasarkan perhitungan indeks gain, didapatkan bahwa gain untuk kelas eksperimen adalah sebesar 0,705. Nilai ini diinterpretasikan termasuk kategori tinggi. Dengan kata lain kemampuan mahasiswa dapat meningkat setelah diberikan pengembangan model pembelajaran Passing atas bola voli berbasis permainan. Pengembangan model pembelajaran Passing atas bola voli berbasis permainan efektif layak digunakan.

\section{DAFTAR PUSTAKA}

American Sport Education Program. (2008). Melatih Bolavoli Remaja, Yogyakarta: Citra Aji Parama.

Bojanic, Danilo, et al. (2016). Influence of a basic motor potential on the realization of specific motor skills of elite female volleyball players. Pitesti: Journal of Physical Education and Sport. Vol. 16, Iss. 2.

Borg, W.R \& Gall M.D (1989), Education Research an Introduction. New York: Longman.

Cimenli, Ozkan, et al. (2016). Effect of an eight-week plyometrictraining on different surfaces on the jumping performance of male volleyball players. Pitesti: Journal of Physical Education and Sport. Vol. 16, Iss. 1.

Emzir. (2012). Metodelogi Penelitian Pendidikan Kuantatif \& Kualitatif. Jakarta: PT Rajagrafindo Persada.

Jlassi, Mourad M., et al. (2019). Objects Detection by Singular Value Decomposition Technique in Hybrid Color Space: Application to Football Images, International Journal of Computers Communications \& Control, Vol 14, No 1

Hamalik, Oemar. (2012). Proses Belajar Mengajar. Jakarta: Bumi Aksara.

Rahyubi, Heri. (2012). Teori-teori Belajar dan Aplikasi Pembelajaran Motorik: Deskripsi dan Tinjauan Kritis, Nusamedia Majalengka.

Husdarta, J.S. (2010). Sejarah dan Fisafat Penjas. Bandung: Alfabeta.

Gurvitch, Rachel \& Metzler, Michael. (2013). Aligning Learning Activities with Instructional Models, Journal of Physical Education, Recreation \& Dance, v84 n3 p30-37 2013.

Kleinmann, Theo. (2012). Bola Voli Pembinaan Teknik, Taktik dan Kondisi. Jakarta: PT Gramedia.

Rahyudi, Heri. (2012). Teori-teori Belajar dan Aplikasi Pembelajaran Motorik. Bandung : Nusa Media. 
Rohendi, Aep \& Suwandar, Etor. (2017). Metode Latihan dan Pembelajaran Bolavoli Untuk Umum. Bandung: Alfabeta.

Subroto, Toto \& Yudiana, Yuyun. (2010). Permainan Bola Voli. Bandung : Fakultas Pendidikan Olahraga dan Kesehatan, Universitas Pendidikan Indonesia.

Sudjana, Nana. (2011). Teori Belajar Untuk Pembelajaran. Bekasi: Bibna Mitra Publishing.

Sugiono. (2011). Metode Penelitian Kuantitatif, Kualitatif, dan R\&D. Bandung: Alfabeta.

Trianto. (2012). Model Pengembangan Terpadu. Jakarta: Bumi Aksara. 